\title{
Exploring the impact of orientations on hospital-supplier collaboration: an empirical study
}

\section{Santanu Mandal*}

Department of Business Analytics,

GITAM Institute of Management,

GITAM (Deemed-to be University),

Rushikonda, Vishakhapatnam-530045,

Andhra Pradesh, India

Email: shaan.nitw@gmail.com

*Corresponding author

\section{Sreejith Nair, Arjun Sreedhar and Uthra Vijeshwari}

\author{
Amrita School of Business, \\ Amrita Vishwa Vidyapeetham, \\ Ettimadai, Coimbatore, 641112, India \\ Email: sreejith563@gmail.com \\ Email: arjuncsk@gmail.com \\ Email: uthravijeshwari95@gmail.com
}

\begin{abstract}
With increasing complexity in healthcare service supply chain operations, there is a dire need to critically examine the enablers of collaboration in a hospital-supplier setting. While studies have stressed the importance of collaboration in service SCs, still the importance of strategic orientations are yet to be explored in the development of hospital-supplier collaboration. We focused on four such strategic orientations relevant for healthcare SCs: technology orientation, supply chain orientation, learning orientation and environmental orientation in developing hospital-supplier collaboration. Furthermore, we also explore the inter-relationships among these orientations. Perceptual responses collected from 92 hospital managers were analysed using SmartPLS 2.0.M3. Results suggested technology, supply chain and learning orientations as prominent enablers for hospital-supplier collaboration. Environmental orientation may inhibit the collaboration process if both parties do not agree on environmental issues. Implications were provided for theory and practice.
\end{abstract}

Keywords: healthcare; collaboration; orientation; technology; supply chain; learning; environmental.

Reference to this paper should be made as follows: Mandal, S., Nair, S., Sreedhar, A. and Vijeshwari, U. (2022) 'Exploring the impact of orientations on hospital-supplier collaboration: an empirical study', Int. J. Services and Operations Management, Vol. 42, No. 1, pp.52-74.

Biographical notes: Santanu Mandal is an Associate Professor in the department of Operations and Systems at Amrita School of Business, Amrita Vishwa Vidyapeetham. He was a Visiting Scholar to Spears School of 
Business, Oklahoma State University, USA. He has published in several international journals like Journal of Production Research, IJOPM, Journal of Business and Industrial Marketing, etc. His research interests typically include healthcare operations, technology management, tourism services and sustainability in operations and services.

Sreejith Nair is a post graduate student at Amrita School of Business, Amrita Vishwa Vidyapeetham.

Arjun Sreedhar is a post graduate student at Amrita School of Business, Amrita Vishwa Vidyapeetham.

Uthra Vijeshwari is a post graduate student at Amrita School of Business, Amrita Vishwa Vidyapeetham.

This paper is a revised and expanded version of a paper entitled 'Exploring the impact of orientations on hospital-supplier collaboration' presented at Global Health \& Medical Tourism Conference 2019, IIM Kozhikode, 7-9 March 2019.

\section{Introduction}

Health care sector is in India's prime sector that contributes to of revenue and employment. This market has a three-fold growth up to Rs 8.6 trillion by the year 2022 . It comprises of medical equipment, clinical trials, subcontracting, medical tourism, and medical health insurance. The healthcare distribution system of India is characterised into public and private. The country is believed to house a lot of opportunities and is one of the principal terminus for high-end investigative facilities with far-fetched capital investment for cutting-edge medical equipment and facilities that serves to a larger share of population. Besides, Indians availing medical help have become more mindful towards their health issues (ref. http://IBEF.org, 2018). A collaboration of suppliers, service providers, consumers etc. is essential to support the resource transactions. This is required to yield services and transforming in such a way that they deliver supporting services and core services (Baltacioglu et al., 2007).

A supply chain service basically consists of three parties namely customer, service provider, and an initial service producer. These three parties need to work in close coordination with each other for rendering smooth services to the consumer. Lately, the Indian Government adopted quite a lot plans fostering the health care sector. For example, PMJAY inventiveness to provide health insurance worth Rs 500,000 to over 100 million families every year (ref. PIB release, dated 23.9.18); Mission Indradhanush have the aim of refining exposure of immunisation in the country (ref. PIB release, dated 10.8.18); Health Protection Mission contributed by both centre and state government to protect people by prevention of diseases through vaccination (circular in http://india.gov.in) ; For the medical service penetration into the rural areas, 3,000 medical stores were setup; for the welfare of senior citizen additional healthcare coverage is provided with monetary benefits up to 30,000 INR. Still the country remains underdeveloped in terms of healthcare sector. It requires a collaboration of many supply chain members. Extensive research was done to realise the relevance of supply chain 
management in the healthcare business. This resulted in the research of supply chain collaboration and supply chain integration (Chakraborty et al., 2014).

Supply chain perspective is necessary for healthcare to control rising costs and to enhance service delivery to consumers. The realisation of the perspective is feasible only if the key objects in healthcare supply chains are integrated. The relationship between the entities impacts the performance of the firm. Integration and individual efforts should be practiced contemporarily to achieve an enhanced performance. Studies use the terms collaboration and integration interchangeably. Integration is process focused with a goal of amalgamation at various levels of operations. Collaboration is all about governance through relational means and contract means. Hence, collaboration syndicates both method and affiliation focus in its conceptualisation.

Existing exploration on sustainability of supply chain management validates pros and cons in terms of cost and benefits of generating supply chains which are sustainable and ways to accomplish them. However, there is still a need for deeper consideration of the sustainability viewpoints of individual executives and the association among those viewpoints and supply chain management (Defee and Fugate, 2010).

In recent times health care is facing many challenges. The main challenge is due to the Healthcare providers and institutions are facing issues with inefficiencies. This helps to achieve an optimal equilibrium between monetary efficiency developments and quality health services (Dillon and Prokesch, 2010). Supply chain fees can support more than $25 \%$ of the operating budget of a hospital, but the healthcare business could deliberately expand its ability to offer services and healthcare amenities of respectable quality to consumers and save nearly $\$ 11$ billion (CSC Consulting, 1996). Many authors mentioned opportunities savings which is not at present undermined by organisations due to inadequacies in the supply chain, such as unproductive inventory and resource management. Insufficient purchasing orders and misrepresentation have a critical impact on the transport and delivery of goods to the medical service providers. The lack of collaboration between healthcare units is an important issue generating these inefficiencies.

Different levels of collaboration in the chain have been known as a means of making supply chains more efficient and reactive, so we offer customers incomparable value (Matopoulos et al., 2007). Wide are studies took place in automotive and electronics sector but only a few studies have been conducted that is related with healthcare sector. The purpose of this research is to understand the development of hospital-supplier collaboration from an orientation perspective. The antecedents are technological, learning, environmental and supply chain orientation. This paper talks about the relationship between the antecedents and the impact of these antecedents on the collaboration of hospital and suppliers.

\section{Literature review}

To enable smooth functioning of a firm, there should be a proper flow of goods and services along the value chain. But what most firms ignore is the importance of symmetric information. There should be proper flow of information throughout the chain, from procurement of supplies till it reaches the end consumer. The entities must synchronise with each other throughout the process until the delivery of service. Co-ordination is important for the overall performance of the firm. 


\subsection{Supply chain co-ordination}

To understand supply chain coordination process we reviewed papers in which the authors designed policies and models to improve supply chain coordination. Planning phase of a supply chain asks for great deal of attention. Schmitt and Snyder (2012) anticipated that during the planning stage there are chances of occurrence of disruptions in demand. In order to handle such disruptions, developing a supply chain coordination scheme to revise the plan will be more promising than proposing alternate ways for dealing uncertainties. The proper and accurate forecasting of contingencies is unattainable. Practically it is not possible to estimate the demand and deviation cost. This ambiguity led to further research and Argote (1982) proposed the ways to achieve proper supply chain coordination that would result in the effectiveness in an organisation. Emergency units which experienced low uncertainty, programmed means of coordination was appropriate and those which experienced higher uncertainty, non-programmed ways worked well.

Further data collection and analysis by Netting et al. (1990) who examined four policies which intended to improve co-operation in addition to co-ordination at various levels in hospital-based management systems in their research. The data collected was secondary through the paper of Simmons and White (1999) in which interviews of hospital managers and discharge planners were conducted. The purposes of the policies are the analysis of hospital involved and the parties involved were to find the implications of the policies. The result indicates that the policy which covers all the disciplines and takes care of the cost aspect as well would be the most feasible policy the policy $\mathrm{C}$ the co-operation across hospital system was favoured in this paper. Supply chain management study focused primarily on supply chain coordination (SCs) in which control is unified. A centralised control involves the presence of an exclusive decision maker in the SC, who's duties is to retain all the information relevant to decision making on the whole SC as well as the contractual power to implement such decisions. Giannoccaro and Pontrandolfo (2002) recommend a supply chain contract model intended to organise a three-phase SC built on the revenue-sharing mechanism. Such a model makes it possible to attain system effectiveness and also improving the returns of supply chain members by adjusting their contract parameters. Various types of ambiguity besides change require different capabilities for effective managerial responses. These responses were related to the flexibility and agility strategic competencies, with the exploration focused on organisation's functions and processes.

Another model was worked upon by Fayezi et al. (2017) using a three-stage modification technique by means of which they collected reviews of about 83 peers. For this extensive search data lessening procedures were used. The procedures include: codification, strings of sentences and keyword review, title, conclusion and abstract. Cachon (2003) in his paper on supply chain and coordination examines several models for supply chain to find the optimal actions in each. The paper mainly concentrates on the newsvendor model in which it deals with the way retailers can fix on the retail price along with the stocking quantity. Here also the issues confronted by the retailer in terms of coordination, is being discussed broadly. The challenges that the retailer face for the coordination is also explored in the infinite horizon stochastic demand model as well. Few more papers were reviewed for understanding the importance of orientations. It is positioning and overall insight into the firm's performance. The papers reviewed help us understand the strategic orientations and their relationship with each other. 


\subsection{Strategic orientations}

\subsubsection{Technology orientation}

It is the tendency or behaviour of an individual/organisation to foster one's skill by valuing the internet and other technological peripherals, thus retrieving trustworthy sources of info for solving problems. Staying updated regarding the new technological advancements is also necessary. Once a problem is identified using this process, it is important that a workaround is formulated for arriving at a solution, which is discussed in the following literature. Kobayashi et al. (2005) stated that high pressure conditions workarounds helps to coordinate the work. Workarounds are practices that are followed so as to overcome the hurdles that prevent an organisation from attaining its aim. In order to identify the differences in workarounds of different people based on their roles, technology plays a vital role. These workarounds cause gushing effect on other workarounds. These workarounds help an organisation to find different business solutions to enhance the coordination among different departments. The matrix that aids in achieving the collaboration is discussed by Garcia-Dastugue and Lambert (2003) explaining the framework of internet enabled co-ordination mechanism to fit various business situations. Using six dimensions, six market mechanisms are evaluated, namely specificity of assets, product description, complexity, risk of transaction, operational risk, risk of operational performance, frequency and value of item. The internet enabled co-ordination mechanisms are analysed using co-ordination flows and market mechanisms. For that, an EDI network was established. The data collected is Primary data which is obtained through interviews of supply chain managers of companies in Columbus. The result of the interviews specifies that the integration of retailer and the manufacturer's supply will be efficient and implementation of price reverse option is also suggested.

Learning is a continuous process which must take place in a company at every stage for constant improvement of skills by gathering knowledge. To stay technologically oriented, learning must happen for implementing the right technology at the right time. The organisation's technical expertise is an important aspect in the development of new procedure, products and services. Thus, it's relevant to discuss the learning orientation.

\subsubsection{Learning orientation}

Learning orientation is tendency that an individual/organisation has so as to nurture ones/its skill set. This helps organisation to accomplish supremacy over a job and ultimately benefits in solving problems.

This mastery over a job is essential in understanding the conflicts and better work pattern. De Clercq and Belausteguigoitia (2017) suggested a positive relationship between the ingenuity and task conflict. This relation is enhanced by learning orientation and degraded goal congruence. Xu et al. (2001) tried to explain how the supply chain coordination (SCC) could be enhanced with the help of exchange of information and forecasting. This paper aims at finding ways to decrease the resource wastage for both the retailers and the manufactures with effective coordination. The study conveyed how the decisions taken by the individuals in a supply chain can result in forecasting errors and other negative effects to the whole supply chain. The authors tried to incorporate the measures to determine the fluctuations and its controlling in a supply chain. It also 
extended the scope of the study in retaining the customer loyalty with effective coordination programs.

Effective coordination is also attained through practicing and implementing innovative ideas in the process. This has a direct impact on the ability of an organisation to perform under critical situations. Learning orientation and innovative performance have directed relation with organisational performance which is arbitrated by knowledge-based resources (Kaya and Patton, 2011).

The leaders who encourage their supporters' creativity can generate sustainable competitive advantage when united with interest of employees' interest in learning (Jyoti and Dev, 2015). Interest and curiosity in learning new ideas is a quality that employees possess. Such employees are assets to the company the knowledge gain can be transferred to other employees through seminars and other short sessions. The link between learning orientation and companies' performance is wholly arbitrated by organisational learning (Real et al., 2014). Likeliness of error reduction is another earning with better learning. When employee autonomy is increased the probability of error occurrence is diminished (Stern et al., 2008).

\subsubsection{Environmental orientation}

Environmentally oriented means to be concerned about the surrounding, aware of the environment and nature. Chan et al. (2012) study tries a model outlining the association among orientation of environment, performance of the firm, and green supply chain management initiatives. They collected around 194 responses from capitalised enterprises operating in China. The findings explain the importance for firms which are functioning in an extremely competitive market to cultivate a corporate culture that supports environmental aspect and improve understanding to important external stakeholders' demands relating to environment.

Corporate have a great part to play in contributing towards environmental orientation. Banerjee (2002) observes perceptions of managers in relation to corporate environmentalism, which is the method that firms use to integrate their concerns of environment and transfer to their decision making through which environmental concerns can be addressed. Two themes of corporate environmentalism are discussed in this paper which are orientation of corporate environment and focus on environmental strategy. Mail survey of around 311 managers had been done through various tests. The study also provides a corporate focus on environmental issues. It goes beyond technical environmental solutions that are the basis of most environmental management programs.

Firms encouraged initiatives oriented environmentally believing to raise their brand esteem. Crane et al. (2008) studied whether a company's environmental orientation impacts corporate brand esteem. This paper watches corporate environmentalism from two viewpoints: ecological embeddedness - the dimension to which environmental values are incorporated in brand identity; and natural execution - the dimension of a company's agreement with natural approaches and great practices. The end result is that the administrators are exhorted not to invalidate corporate social duty, yet rather invest wisely in environmental activities and its communication.

This orientation further explores the possibility of environmental collaboration as a perspective, which evidently echoes a fair amount of understanding of the responsibilities of both the parties and capabilities in connection with the management of environment (Blome et al., 2014). This will not only lead to a better understanding of the operations of 
the stakeholders, but at the same time signal a long-term willingness to acknowledge the similarities and differences along the process of collaboration. Thus, environmental collaboration focuses less on the short-term consequences of environmentally inclined efforts, rather presses concern over designing products that are more environmentally sound.

\subsubsection{Supply chain orientation}

Esper et al. (2010) proposed the concept to grow an element of structure for SCO together with the areas ranging from human resources, IT, organisational design and measurement of organisation. The concept that was proposed, captures the core concerns of positioning an organisation for the success of the supply chain more efficiently. Croom et al. (2018) studies SCO's relationship with sustainable performance in the supply chain. Nevertheless, the previous papers did not determine whether SCO directly affects supply chain performance sustainability. The results were that the SCO of supply chain collaboration and communication could directly affect both the environmental supply chain and social sustainability performance. These conclusions specify that supply chain's sustainability performance is affected by different supply chain orientations constructs.

Janaína et al. (2007) stated that by creating avenues, numerous ventures are looking for provincial and manageable improvement by attempting to promote local products and companies. This paper seeks to evaluate the state of SCO for improvement in the structure and execution of businesses in two Brazilian Amazon states. The evaluation was obtained by blending the six ventures with contextual investigation and experimental information. The end displays the yields of the examination, which can be helpful to comparative tasks, particularly those identified with the structure of feasible and provincially adjusted preparations and production network setups.

\subsection{Hospital-supplier collaboration}

There is a dire need to explore about nature and impact of supply chain collaboration in manufacturing and services. Cao and Zhang (2011) considered independent variables as supply chain collaboration, collaborative advantage and firm and dependent variable size as firm performance. The primary data is gathered through a web survey of 5,000 supply chain management professionals around the council. Effective supply chain collaboration has been found in seven interconnecting dimensions: information sharing, collaborative communication, goal congruence, decision synchronisation, incentive alignment, resource sharing and joint knowledge creation. Supply chain collaboration variables and collaborative advantage have a noteworthy influence on the company's performance.

Various aspects of collaboration were suggested by Esper et al. (2007) who stated that mechanisms for supporting price, non-price, and flow coordination lead to their increased performance in supply chain. Proper collaboration among firms and its suppliers is another major factor. When the entities collaborate, the vision is unified, knowledge is shared and the result is enhanced performance of the firm. In order to comprehend concept of collaboration better, papers on collaboration among supply chain and its members and its impact were studied.

Researchers pointed out that it is essential for individual supply chain members to organise by agreeing a set of transfer payments in order to achieve the goal of supply 
chain. Cachon (2003) stated that, since coordination of supply chain needs capacity amount, Supplier builds and depend on the demand forecast, supply chain coordination can only be attained if demand forecast is shared correctly. Organisations can regulate their trading terms through an agreement establishing transfer of payment scheme to generate an incentive. Supply chain collaboration - 'the capacity to work across organisational limits to shape and manage inimitable value-added processes' has been advertised as a foundation of differential firm performance. Supply chain collaboration 'the capacity to work across organisational limits to shape and manage inimitable value-added processes' has remained advertised as foundation of differential performance of the firm.

Wilder and Stanley (2015) say organisations could seek to add balancing capabilities to create value when working aids collaboratively offset their costs, which they could not achieve self-sufficiently. A comprehensive search of keyword literature through ABI Inform and ProQuest databases and managerial interviews was undertaken to understand the concept of relationships. It has been learned that understanding complex interactions between relational resistors offers insight desirable to mitigate effectively. A possible correlation between coordination and social network was explored by Hossain and Guan (2012). Many patients around the globe face access block issues where they are getting delayed service from doctors within the emergency department. According to Fatovich et al. (2005) inefficient performances in turn disturb the coordination and eventually instigate access blocks. He also states that albeit the relation between the coordination and social network it cannot be the only possible reason.

Recent IT advances empower organisations to increase the degree of collaboration with their trading partners and create more dense coordination of their supply chain events Coordination mechanisms are at the central of supply chain administrative practice besides research, which are gears to address specific coordination issues. Stern et al. (1996) stated that these procedures, widely used in industry, are involved in eradicating sub-optimisation of the supply chain and achieving the required performance results. Dyer and Singh (1998) suggested that multiple firms can work together as a network so as to create a competitive advantage with mutual benefits. Secondly, they have figured the detaching mechanisms that conserve the relational rents made through effective firm to firm collaboration. Third, a relational perspective can provide normative remedies for managers involved that contradict the prescriptions offered by the opinion of resource-based view and the structure of industry.

Further, some of the researchers wanted to know the reasons for failures of collaboration. Fawcett et al. (2015) expressed in the article, the theories which could articulate failure of collaboration strategies and its causes. The methodology used for the study was with the help of interviews with managers which was done in two different periods namely period 1 and period 2 with 49 companies and 57 companies in the respective periods. The study basically identified on how the resistors such as sociological and structural could reinforce together so that the collaborative behaviour is eroded away. The authors were successful in figuring out and explaining the reasons behind the factors which led to the failure of the collaboration in the supply chain.

Ren et al. (2014) conducted a similar study explaining the concept of collaboration with help of a case study in a hospital to portray the complexity the importance of coordination in such environments. The study tried to present the difficulties faced in this organisation with respect to the coordination part is concerned and the support it attained 
from information technology. Throughout, the study was reviewed with the idea of trajectory focus which showed three factors whose absence led to the failure in coordination among the large number of groups in the firm. The paper ends by suggesting technological improvements that can assist in gathering the information and examine the coordination in similar complex environments.

\section{Hypotheses development}

The positioning and overall insight of an organisation's activities is what Orientation means, and this concept has been applied in many facets of research, like entrepreneurship, marketing and stakeholder theory (Berman et al., 1999). The company's internal technology strategy replicates its innovative assertiveness and pledge to innovation (Al-Ansari et al., 2013). Research has proved that superior financial performance can be attained through efficient environmental strategy and also orientation (Fraj et al., 2015). The factors such as technology, resources used etc. drive a firm to be environmentally oriented. Firms that have a high technology orientation have better responses towards environmental issues. Chan et al. (2012) states the benefits of performing green supply chain management activities in organisations and how it could reap enhanced performance. For organisations like medical institutions which is a part of highly competitive market, the pro-environmental company culture is to be fostered by practicing greener supply chain management. This enables the organisation to satisfy the stakeholders' environmental demands. This gives our next hypothesis:

H1 Technology orientation has positive impact on environmental orientation

Further with greater TO, firms in healthcare SCs can learn from one another. This is because TO helps healthcare SC firms to share information with one another, aiding in knowledge exchange and learning process. Firms that possess stout learning orientation will eventually perform successful innovation. Such organisations in turn incorporate those technological orientations (Baker and Sinkula, 1999). Hence, we hypothesise that:

H2 Technology orientation has a positive impact on learning orientation.

As service sector, i.e., healthcare SC firms can gain skilled with latest technologies and deploy the same in to their everyday activities. There is higher suitability to coordinate with their SC partners. This helps them to develop an integrated approach in focusing on $\mathrm{SC}$ issues and development, rather than being focused on individual development. Boon-Itt and Wong (2011) states identified that the influence of supplier integration on delivery performance can become significant. This happens if the technological uncertainty is high enough. Hence, we hypothesise that:

H3 Technology orientation has a positive impact on SC orientation.

The propensity to learn through sharing of exchange and real-time information in service SCs help greatly in achieving environmental awareness. Firms tendency to operate in a manner providing least damage to the environment is also dependent on the eagerness to learn from one another. Similarly, responsiveness of a supplier is an important variable in the recent supply chains (Sinkovics et al., 2011). Firms with better technological orientation, adapt comparatively quicker to the environmental changes. Technically oriented firms have the ability to adapt quickly to the environmental changes. Kirchoff 
et al. (2016) suggests that both the supply chain and environmental orientation competence of the any organisation have a positive impact on supply chain management activities. This provides a great learning opportunity to understand how managers shape and reshape the environmental capabilities to compete in an ever-changing business environment. This suggests that:

H4 Learning orientation has a positive impact on environmental orientation

Further with higher LO, firms in healthcare SCs stand in a better position to develop integrated efforts with their key partners. IT helps in identifying supply chain information regarding the demand and supply and to understand the process. IT can also be a single point of contact to access the data information (Simchi-Levi et al., 1999). Amidst implementing various learning in supply chain collaborative activities, feedback can be used to further improve the collaborative advantages which in turn help in performing efficient and effective hospital-supplier relationship. This suggests that:

H5 Learning orientation has a positive impact on SC orientation.

In order to facilitate and withstand a competitive advantage in the supply chain area, extensive research indicate that sharing of knowledge and learning are major factors (Lambe et al., 2002; Cheng, 2011). Wowak et al. (2013) current meta-analysis approves the significance and status of manipulating SCM-related knowledge to attain greater performance. It has been observed that in the logistics and supply chain field, manufacturing companies look to develop a co-operative and mutually advantageous relationship with the suppliers (Tan et al., 2002). The process of learning adopted by LO culture is fundamentally enabling SCO in creating value when there is a continuous generation and dissemination and sharing of knowledge in a hypercompetitive global environment. So, we hypothesise that:

H6 Environmental orientation has a positive impact on HSCOL.

Information of condition is vital for capacities improvement and clinics as essential firms in the restorative supply chains can procure prevalent execution by extending their experience through supply network relationship (Birkinshaw et al., 2016). Acquiring data in regards to varieties in market by working with merchants and clients (e.g. patients) is noteworthy for advancement and improvement of new items and administrations. Similarly, chiefs in medical clinics need to comprehend external information for identification of chances and developing them (Teece, 2012). Consequently, learning introduction helps clinics just as their providers work together viably. This leads way to the next hypothesis:

\section{H7 Learning orientation has a positive impact on HSCOL.}

Knowledge, which is inspired by state-of-the art facility can offer stretchy and innovative setting for learning (Bines and Jamieson, 2013). Advancement in learning and technology along with its relation and impact on the nature is not intellectualised properly (Nordquist and Laing, 2015). Chakraborty et al. (2014) established that the hospital supplier collaboration is dependent on value co-creation. Value co-creation (VCC) catalysis the association between hospital supplier collaboration and VCC. LO consists of commitment towards learning, sharing of vision, open-mindedness as wells as sharing of inter-organisational knowledge. Such enhanced shared vision, impartiality, and 
information sharing helps hospitals and suppliers to collaborate with each other more effectively. Hence, we hypothesise that:

$\mathrm{H} 8 \mathrm{SC}$ orientation has a positive impact on HSCOL.

\section{Methodology}

\subsection{Data collection and sample demographics}

Since we are focusing on healthcare supply chain and issues that contribute to hospital-supplier collaboration, the study selected hospital managers as potential respondents for data collection. Furthermore, hospital managers were selected as they have accurate idea of their collaboration issues with their key suppliers. Furthermore, they are also potential respondents' having accurate idea of the orientation status in their hospitals and their likely influence in shaping their collaborative efforts with their key suppliers. The study relied on several online portals for gathering the potential contacts of hospital managers. Furthermore, with the help of a consultancy, we were able to get 437 contacts. The study sent a link with the questionnaire for responding to the survey items. The link included brief definitions of the terms and survey overview, along with confidentiality assurance. Around 97 partially completed responses were received yielding a response rate of $22.19 \%$ (97/437). Such a response rate in online surveys is fairly acceptable (Visser et al., 1996; Dillman, 2011) and may yield more accurate results than higher response rates (Visser et al., 1996) normally. Furthermore, the selection of hospital managers as potential respondents ensured that the questions are directed to the right audience. This is because the hospital managers are the only entities who are likely to have the most accurate idea of operational, tactical and strategic issues. Furthermore, the majority of the sample respondents had well above five years of experience in their field. The minimum experience noted in the respondent sample was three years. This further ensured that the sample is representative for the study. The study proceeded for hypotheses testing with 92 complete responses. We have also done a t-test to explore any significant differences between hospital managers and manager-operations. The results were insignificant showing no differences. The below table show the sample characteristics.

\subsection{Path modelling and hypotheses testing}

Studies widely encourage the use of partial least squares where the prime focus is association testing in the presence of non-normal data, formative factors (Peng and Lai, 2012; Hair et al., 2012; Ajamieh et al., 2016) in operations and services. This has led to the usage of SmartPLS 2.0.M3 (Ringle et al., 2005) for hypothesis testing in several disciplines. Furthermore, PLS offers the researchers more flexibility in terms of basic assumptions while testing for hypotheses, compared to OLS (Peng and Lai, 2012; Hair et al., 2006, 2011, 2017a, 2017b, 2018; Richter et al., 2016). Consequently, we use PLS in this study since the prime objective is association analysis. In PLS, we adhered to the criteria of sample size adequacy: total measures greater than 10 times of that of largest factor present in the model (Ali et al., 2018). Furthermore, the boot strapping 
analysis were conducted using 92 cases and 5,000 sub-samples for stability of the significant paths (Peng and Lai, 2012; Ali et al., 2018; Hair et al., 2014, 2011; Henseler et al., 2016).

Table 1 Sample profile

\begin{tabular}{lcc}
\hline Designation & No. & $\%$ \\
\hline Hospital manager & 63 & 68.48 \\
Manager-operations & 29 & 31.52 \\
Age & & $\%$ \\
less than 30 years & 41 & 44.57 \\
30-35 years & 24 & 26.09 \\
36-40 years & 16 & 17.39 \\
41 years and above & 11 & 11.96 \\
Experience & & \\
less than 5 years & 32 & 34.78 \\
5-10 years & 26 & 28.26 \\
$10-15$ years & 14 & 15.22 \\
15 years and above & 20 & 21.74 \\
\hline
\end{tabular}

Table 2 Item loadings and t-stats

\begin{tabular}{lcc}
\hline Technology orientation (TO) & Loadings & t-stats \\
\hline [Adapted from Zhou and Li (2010) and Mandal (2018)] & & \\
Alpha $=0.973 ;$ CR $=0.979 ;$ AVE $=0.905$ & 0.935 & 49.833 \\
$\quad$ utilise advanced technologies in routine operations & 0.931 & 40.243 \\
$\quad$ utilise recent technologies to develop innovative services & 0.968 & 109.016 \\
$\quad$ are always ready to embrace innovations in technology & 0.957 & 80.420 \\
$\quad$ use advanced technologies for execution of relevant operations & 0.965 & 118.252 \\
$\quad$ are always ready to accept advanced technologies for execution & & \\
\hline Environmental orientation (ENVO) & & \\
\hline [Adapted from Kirchoff et al. (2016)] & 0.835 & 15.179 \\
Alpha $=0.938 ;$ CR $=0.953 ;$ AVE $=0.803$ & 0.934 & 48.612 \\
$\quad$ work together so that operations are executed in an eco-friendly & & \\
$\quad \begin{array}{l}\text { manner } \\
\text { together tries to reduce the negative impact of operations on the } \\
\text { environment }\end{array}$ & 0.924 & 36.863 \\
$\quad \begin{array}{l}\text { execute programs targeted to ensure sustainability remains a key in } \\
\text { strategic decision making for all }\end{array}$ & 0.861 & 20.996 \\
$\quad \begin{array}{l}\text { ensures that their firms develop environment friendly strategic plans } \\
\text { constantly puts up an effort for developing an eco-friendly image }\end{array}$ & 0.924 & 58.618 \\
\hline
\end{tabular}

Notes: All constructs were measured on a 7-point Likert scale with $1=$ strongly disagree and $7=$ strongly agree. ${ }^{*} \mathrm{HSC}=$ healthcare supply chain; for the orientations...items are to be read as 'Your HSC members ....'. 
Table 2 Item loadings and t-stats (continued)

\begin{tabular}{|c|c|c|}
\hline Learning orientation $(\mathrm{LO})$ & & \\
\hline [Adapted from Deutscher et al. (2016)] & & \\
\hline Alpha $=0.933 ; C R=0.949 ; A V E=0.789$ & & \\
\hline prioritises learning for ensuring sustainability and growth & 0.891 & 28.049 \\
\hline $\begin{array}{l}\text { encourages employees to share their experiences to ensure employee } \\
\text { growth }\end{array}$ & 0.905 & 32.775 \\
\hline $\begin{array}{l}\text { urges their employees to work in close coordination for successful } \\
\text { synchronisation }\end{array}$ & 0.899 & 31.166 \\
\hline $\begin{array}{l}\text { encourages their employees to learn from each other for innovative } \\
\text { idea generation }\end{array}$ & 0.843 & 17.868 \\
\hline encourages innovation through individual and group learning & 0.904 & 31.021 \\
\hline Supply chain orientation (SCO) & & \\
\hline [Adapted from Kirchoff et al. (2016)] & & \\
\hline Alpha $=0.951 ; C R=0.962 ; A V E=0.836$ & & \\
\hline work together for ensuring sustainability of SC relationships & 0.907 & 37.370 \\
\hline considers trust as a key element for relationship continuity & 0.890 & 29.775 \\
\hline $\begin{array}{l}\text { looks at integrated effort across the chain for ensuring sustainability } \\
\text { of operations }\end{array}$ & 0.936 & 71.309 \\
\hline $\begin{array}{l}\text { tries to sync their goals with one another for ensuring sustainability at } \\
\text { the supply chain level }\end{array}$ & 0.899 & 34.605 \\
\hline $\begin{array}{l}\text { recognises the need of supply chain management for ensuring } \\
\text { strategic performance }\end{array}$ & 0.941 & 93.202 \\
\hline Hospital-supplier Collaboration (HSCOL) & & \\
\hline [Mandal (2017)] & & \\
\hline Alpha $=0.958 ; C R=0.968 ; A V E=0.859$ & & \\
\hline Your firm distributes rewards evenly with prominent suppliers & 0.948 & 54.820 \\
\hline $\begin{array}{l}\text { Your firm always coordinates its execution decisions with prominent } \\
\text { suppliers }\end{array}$ & 0.94 & 40.153 \\
\hline $\begin{array}{l}\text { Your firm's main suppliers always interact while taking significant } \\
\text { decisions }\end{array}$ & 0.956 & 98.005 \\
\hline $\begin{array}{l}\text { Your firm and its prominent suppliers has a clear understanding of } \\
\text { each other' goals and priorities }\end{array}$ & 0.877 & 23.486 \\
\hline $\begin{array}{l}\text { Your firm produces demand forecasts in collaboration with its } \\
\text { prominent suppliers }\end{array}$ & 0.911 & 28.973 \\
\hline
\end{tabular}

Notes: All constructs were measured on a 7-point Likert scale with $1=$ strongly disagree and $7=$ strongly agree. $* \mathrm{HSC}=$ healthcare supply chain; for the orientations...items are to be read as 'Your HSC members ....'.

Since SmartPLS 2.0.M3 does not produce the HTMT criterion of discriminant validity in its standard output, we have taken help of ADANCO 2.1.1 (Henseler and Dijkstra, 2015) for the same. Furthermore, ADANCO 2.1.1 (Henseler and Dijkstra, 2015) also helped to get a summary of direct and indirect effects. Reliability assessment followed established rules based on composite reliability, Cronbach's alpha and indicator loading $>0.70$ (Hair et al., 2017b). Our items conformed to these tests and showed that they satisfy the thresholds for discriminant validity (Table 3). In addition, we have included in Table 3, the cross loadings as other quality criteria. 
Table 3 Discriminant validity and cross loadings of the items

\begin{tabular}{|c|c|c|c|c|c|}
\hline & ENVO & HSCOL & $L O$ & SCO & TO \\
\hline ENVO & 0.896 & & & & \\
\hline HSCOL & 0.513 & 0.927 & & & \\
\hline LO & 0.309 & 0.46 & 0.888 & & \\
\hline $\mathrm{SCO}$ & 0.327 & 0.519 & 0.588 & 0.914 & \\
\hline TO & 0.276 & 0.225 & 0.232 & 0.219 & 0.951 \\
\hline \multicolumn{6}{|c|}{ Diagonal $=$ Sq.rt of $A V E ;$ below $=$ correlations } \\
\hline & ENVO & HSCOL & $L O$ & $S C O$ & TO \\
\hline COL1 & 0.472 & 0.948 & 0.424 & 0.504 & 0.184 \\
\hline COL2 & 0.508 & 0.940 & 0.414 & 0.477 & 0.178 \\
\hline COL3 & 0.546 & 0.956 & 0.446 & 0.471 & 0.264 \\
\hline COL4 & 0.413 & 0.877 & 0.403 & 0.454 & 0.116 \\
\hline COL5 & 0.430 & 0.911 & 0.447 & 0.499 & 0.294 \\
\hline ENVO1 & 0.835 & 0.423 & 0.202 & 0.250 & 0.291 \\
\hline ENVO2 & 0.934 & 0.415 & 0.279 & 0.232 & 0.246 \\
\hline ENVO3 & 0.924 & 0.494 & 0.355 & 0.340 & 0.273 \\
\hline ENVO4 & 0.861 & 0.402 & 0.213 & 0.251 & 0.166 \\
\hline ENVO5 & 0.924 & 0.540 & 0.310 & 0.366 & 0.250 \\
\hline LO1 & 0.219 & 0.390 & 0.891 & 0.482 & 0.145 \\
\hline LO2 & 0.295 & 0.487 & 0.905 & 0.604 & 0.194 \\
\hline LO3 & 0.309 & 0.450 & 0.899 & 0.529 & 0.296 \\
\hline LO4 & 0.229 & 0.378 & 0.843 & 0.438 & 0.227 \\
\hline LO5 & 0.309 & 0.320 & 0.904 & 0.536 & 0.157 \\
\hline SCO1 & 0.231 & 0.432 & 0.507 & 0.907 & 0.162 \\
\hline $\mathrm{SCO} 2$ & 0.298 & 0.446 & 0.495 & 0.890 & 0.131 \\
\hline $\mathrm{SCO} 3$ & 0.370 & 0.505 & 0.547 & 0.936 & 0.269 \\
\hline $\mathrm{SCO} 4$ & 0.278 & 0.479 & 0.528 & 0.899 & 0.225 \\
\hline $\mathrm{SCO} 5$ & 0.311 & 0.503 & 0.602 & 0.941 & 0.202 \\
\hline TO1 & 0.237 & 0.241 & 0.217 & 0.197 & 0.935 \\
\hline TO2 & 0.285 & 0.216 & 0.204 & 0.187 & 0.931 \\
\hline TO3 & 0.271 & 0.232 & 0.203 & 0.223 & 0.968 \\
\hline TO4 & 0.259 & 0.191 & 0.253 & 0.232 & 0.957 \\
\hline TO5 & 0.259 & 0.193 & 0.223 & 0.199 & 0.965 \\
\hline
\end{tabular}

Next we provide HTMT criterion for assessing discriminant validity. As per established guidelines (Henseler et al., 2015), the values should be $<0.85$. Table 4 satisfies suitably the above criteria. Also the overall model fit was assessed using SRMR that stood at 0.0649. Ideally this should be less that 0.08 (Henseler et al., 2016). Hence the model fit is satisfactory. 
Table 4 Discriminant validity: heterotrait-monotrait ratio of correlations (HTMT)

\begin{tabular}{lccccc}
\hline Construct & $\begin{array}{c}\text { Env. } \\
\text { orientation }\end{array}$ & $\begin{array}{c}\text { SC. } \\
\text { orientation }\end{array}$ & $\begin{array}{c}\text { Tech. } \\
\text { orientation }\end{array}$ & $\begin{array}{c}\text { Hosp. supp } \\
\text { collaboration }\end{array}$ & $\begin{array}{c}\text { Learning. } \\
\text { orientation }\end{array}$ \\
\hline $\begin{array}{l}\text { Env. orientation } \\
\text { SC. orientation }\end{array}$ & 0.3383 & & & & \\
Tech. orientation & 0.286 & 0.2242 & & & \\
$\begin{array}{l}\text { Hosp. supp } \\
\text { collaboration }\end{array}$ & 0.5335 & 0.5418 & 0.2317 & & \\
Learning. orientation & 0.321 & 0.6161 & 0.24 & 0.4816 & \\
\hline
\end{tabular}

Next, we tested robustness of our path values through comparing with OLS coefficients (Table 5).

Table 5 PLS results and OLS results

\begin{tabular}{|c|c|c|c|c|c|c|}
\hline \multicolumn{2}{|c|}{$\begin{array}{l}\text { Summary of hypotheses } \\
\text { testing }\end{array}$} & \multicolumn{3}{|c|}{$P L S$} & \multicolumn{2}{|c|}{ OLS regression } \\
\hline No. & Relationship & $\begin{array}{c}\text { Path } \\
\text { coefficient }\end{array}$ & T-values & Supported? & $\begin{array}{l}\text { Standardised } \\
\text { coefficients }\end{array}$ & $t$-values \\
\hline H1 & $\mathrm{TO}(+) \rightarrow \mathrm{ENVO}$ & 0.216 & 2.056 & Yes & 0.217 & 2.148 \\
\hline $\mathrm{H} 2$ & $\mathrm{TO}(+) \rightarrow \mathrm{LO}$ & 0.232 & 2.058 & Yes & 0.229 & 2.227 \\
\hline H3 & $\mathrm{TO}(+) \rightarrow \mathrm{SCO}$ & 0.087 & 0.957 & No & 0.087 & 0.984 \\
\hline $\mathrm{H} 4$ & $\mathrm{LO}(+) \rightarrow \mathrm{ENVO}$ & 0.259 & 2.276 & Yes & 0.252 & 2.494 \\
\hline H5 & $\mathrm{LO}(+) \rightarrow \mathrm{HSCOL}$ & 0.173 & 1.284 & No & 0.169 & 1.666 \\
\hline H6 & $\mathrm{LO}(+) \rightarrow \mathrm{SCO}$ & 0.567 & 6.671 & Yes & 0.562 & 6.384 \\
\hline H7 & $\mathrm{ENVO}(+) \rightarrow \mathrm{HSCOL}$ & 0.362 & 3.288 & Yes & 0.357 & 4.11 \\
\hline H8 & $\mathrm{SCO}(+) \rightarrow \mathrm{HSCOL}$ & 0.298 & 2.167 & Yes & 0.306 & 2.997 \\
\hline
\end{tabular}

Except $\mathrm{H} 3$ and $\mathrm{H} 5$, the remaining proposed relationships were supported empirically. Of variance explained, findings revealed $14 \%$ in ENVO, $5.4 \%$ in LO, $35.2 \%$ in SCO and $42 \%$ in HSCOL. Following Chin (1998), our model has enough predictive validity. Figure 1 summarised the results in a structural model.

Finally, the study adopted the approach suggested by Zhao et al. (2010) for evaluating mediation effects. A bootstrapping was conducted with 5,000 subsamples to determine the significance of the indirect effects. Now three possible scenarios may arise:

a indirect $\rightarrow$ significant, direct $\rightarrow$ n.s. then it is indirect only mediation

b $\quad$ indirect $\rightarrow$ n.s., direct $\rightarrow$ n.s. implies no mediation

c $\quad$ indirect $\rightarrow$ n.s., direct $\rightarrow$ significant implies direct-only mediation

d $\quad$ indirect $\rightarrow$ significant, direct $\rightarrow$ significant implies complementary or competitive mediation (Zhao et al., 2010).

Table 6 summarises the direct, indirect and total effects along with their significances. 
Figure 1 Results of structural model (see online version for colours)

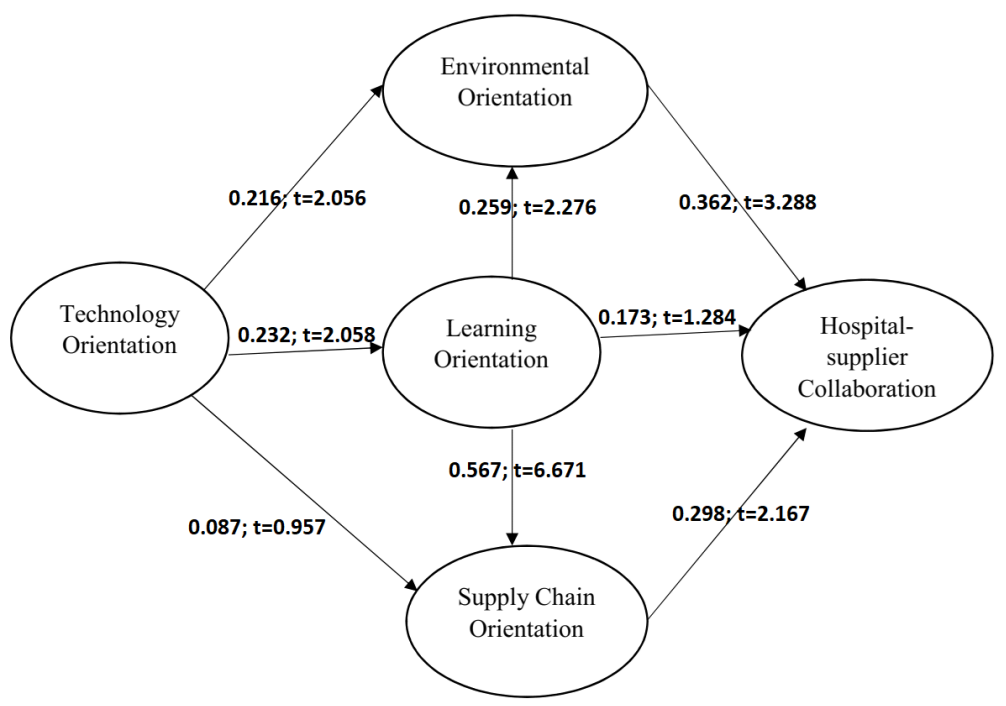

Table 6 Summary of effects

\begin{tabular}{lccccccc}
\hline \multicolumn{1}{c}{ Effect } & Beta & p-value & $\begin{array}{c}\text { Indirect } \\
\text { effects }\end{array}$ & p-value & $\begin{array}{c}\text { Total } \\
\text { effect }\end{array}$ & p-value & $\begin{array}{c}\text { Cohen's } \\
f^{2}\end{array}$ \\
\hline $\begin{array}{l}\text { Env. orientation } \rightarrow \text { Hosp. } \\
\text { supp collaboration }\end{array}$ & 0.361 & 0.001 & & & 0.361 & 0.001 & 0.196 \\
$\begin{array}{l}\text { SC. orientation } \rightarrow \text { Hosp. } \\
\text { supp collaboration }\end{array}$ & 0.299 & 0.015 & & & 0.299 & 0.015 & 0.097 \\
$\begin{array}{l}\text { Tech. orientation } \rightarrow \text { Env. } \\
\text { orientation }\end{array}$ & 0.216 & 0.017 & 0.060 & 0.073 & 0.276 & 0.003 & 0.051 \\
$\begin{array}{l}\text { Tech. orientation } \rightarrow \text { SC. } \\
\text { orientation }\end{array}$ & 0.088 & 0.164 & 0.132 & 0.023 & 0.219 & 0.026 & 0.011 \\
$\begin{array}{l}\text { Tech. orientation } \rightarrow \text { Hosp. } \\
\text { supp collaboration }\end{array}$ & & & 0.205 & 0.002 & 0.205 & 0.002 & \\
$\begin{array}{l}\text { Tech. orientation } \rightarrow \\
\text { Learning. orientation }\end{array}$ & 0.232 & 0.019 & & & 0.232 & 0.019 & 0.057 \\
$\begin{array}{l}\text { Learning. orientation } \rightarrow \\
\text { Env. orientation }\end{array}$ & 0.259 & 0.010 & & & 0.259 & 0.010 & 0.074 \\
$\begin{array}{l}\text { Learning. orientation } \rightarrow \\
\text { SC. orientation }\end{array}$ & 0.567 & 0.000 & & & 0.567 & 0.000 & 0.470 \\
$\begin{array}{l}\text { Learning. orientation } \rightarrow \\
\text { Hosp. supp collaboration }\end{array}$ & 0.173 & 0.096 & 0.263 & 0.003 & 0.436 & 0.000 & 0.033 \\
\hline
\end{tabular}

Now in Table 6, the direct effect of TO on ENVO is significant, however the indirect is not. Hence there is only direct-only mediation for this path. Again, the indirect effect of TO on SCO is significant, however the direct effect is not. Hence there is indirect-only mediation. Furthermore, the indirect effect of TO on HSCOL was significant, suggesting indirect-only mediation. Lastly, the direct effect of LO on HSCOL is not significant, 
however the indirect effect is significant. Hence there is indirect-only mediation for this path.

The study further showed that $\mathrm{H} 3$ and H5 were not supported. This may be due to the fact that mere presence of TO need not suggest that the firms would be having higher SC orientation. The firm managers must conduct training programs for their employees so as to harness the benefits of TO in generating SCO. Furthermore, having learning orientation does not necessary help the hospitals and their suppliers to collaborate more efficiently. This is because there must be good buyer-supplier relationship to ensure collaborative efforts to happen between the two parties.

\section{Theoretical and practical implications}

The study explored the importance of strategic orientations in the development of hospital-supplier collaboration. From a theoretical standpoint, it may be inferred that orientations are firm level resources that when appropriately deployed may result in capabilities, e.g., collaboration with partners. So this study added to the application of RBV (Barney, 1991) in healthcare context through suggesting that SCO and ENVO are prominent resources which when suitably deployed may result in the development of HSCOL. Furthermore, TO is a prominent resource for the development of LO and ENVO. Lastly, LO as a firm level resource also aids in other firm resource development through helping in the development of ENVO and SCO.

The strategic orientations that we have considered are technology orientation, supply chain orientation, learning orientation and environmental orientation which are relevant for healthcare supply chain. We have studied both individual impacts and inter relationship between orientations. Results suggested that technology, supply chain as well as learning orientations as important catalysts for hospital-supplier collaboration. Environmental orientation may inhibit the collaboration process if both parties do not agree on environmental issues. The collaborative benefit and the performance of the company is affected by the collaborative environment of the supply chain. The synergy and superior performance can be achieved through enabling the collaborative advantage. The combined advantage for small firms facilitates the relationship between the company's supply chain collaboration and performance. It has a trivial impact on both medium and large companies (Cao and Zang, 2011).

Supply chain partners should not restrict themselves from interdependencies, when the supply chain is multidimensional. As a product passes from on stakeholder to another, every organisational member, who is part of the complex supply chain, is bound to either add or lose value along the scale (Vanvactor, 2011). We are in an era where the focus has shifted from procurement management to relationship management in any service sector. Our study is twofold-The first part is the study of inter relationship between the orientations. The strategic orientations that we have considered are technology orientation, supply chain orientation, learning orientation and environmental orientation which are relevant for healthcare supply chain. The second is impact of these antecedents on the collaboration of hospital and suppliers. Results suggested that technology, orientations of supply chain and learning act as noticeable enablers for hospital-supplier collaboration. There are enough references to state that the medical knowledge in healthcare sector is scattered across and thus, there is a necessity for organisations to collaborate with suppliers professionally (e.g., Vos and Meijboom, 2004). Our study's 
learning orientation acts as the mediating variable as it plays a vital role in any other strategic orientation.

Our research paper investigated the importance of sharing information for significant performance management in hospital supply chains (Dobrzykowski and Tarafdar, 2015). Our study focused more on learning so firms are well prepared for future changes (Scholten and Schilder, 2015). Environmental orientation may inhibit the collaboration process if both parties do not agree on environmental issues.

In order to ensure that the supply chain is efficient and responsive to market needs, organisations have identified the need for collaboration with partners outside the firms over the past decades. Organisations have continued to work towards greater supply chain collaboration to guide the flow of customers and suppliers 'information and resources (Fawcett and Magnan, 2004; Lejeune and Yakova, 2005).

The collaborative advantage and the firm's performance is affected by the supply chain collaborative environment. It is possible to achieve synergy and superior performance by enabling the collaborative advantage. The benefit of collaboration for small firms facilitates the relationship between the company's supply chain collaboration and performance. It has a trivial impact on medium and large firms (Cao and Zang, 2011). Supply chain partners should not be restricted when the supply chain is multidimensional from interdependencies. As a product moves from one stakeholder to another, each organising member that is part of the complex supply chain is bound to add or lose value to the chain.

The analysis enabled identification of the complex and diverse behaviour of the healthcare SCs. The hospital operations and supplier collaborations were observed and empirical insights were drawn. Cost-competitive nature of the healthcare market has compelled the hospital managers to look for practices that can improve their efficiency and hospital-supplier collaboration is a proven method of achieving this goal. Responses from the hospital managers prove that both hospitals and vendors have operational and financial benefits through this collaboration (Matopoulos and Michailidou, 2013a).

\section{Limitations}

The study showed that EO, SCO as prominent enablers for hospital-supplier collaboration, TO for EO and LO and finally LO for EO and SCO. However, the study has certain limitations. With a sample size of 92, future studies should explore other orientations and their possible influence in the development of hospital-supplier collaboration with a larger sample size. This would aid in increased generalisability and validity. Furthermore, studies should exercise case study research for two or more sector specific organisations to explore the development of hospital-supplier collaboration from the orientations that the firms adopt. Such a longitudinal study would also help to identify the way HSCOL is helping firms in their routines and strategic executions, aided by orientations. Further study should also explore multi-informant approach i.e. multiple respondents from a single firm to further focus on the issues and enhance the validity of the findings. With 92 complete responses for hypotheses testing, the study did not however consider for controlling for age, experience etc. Future studies can therefore examine the impact of considering these as effective control variables. 


\section{References}

Ajamieh, A., Benitez, J., Braojos, J. and Gelhard, C. (2016) 'IT infrastructure and competitive aggressiveness in explaining and predicting performance', Journal of Business Research, Vol. 69, No. 10, pp.4667-4674.

Al-Ansari, Y., Pervan, S. and Xu, J. (2013) 'Innovation and business performance of SMEs: the case of Dubai', Education, Business and Society: Contemporary Middle Eastern Issues, Vol. 6, No. 3/4, pp.162-180.

Ali, F., Rasoolimanesh, S.M., Sarstedt, M., Ringle, C.M. and Ryu, K. (2018) 'An assessment of the use of partial least squares structural equation modeling (PLS-SEM) in hospitality research', International Journal of Contemporary Hospitality Management.

Argote, L. (1982) 'Input uncertainty and organizational coordination in hospital emergency units', Administrative Science Quarterly, Vol. 23, No. 3, pp.420-434.

Baker, W.E. and Sinkula, J.M. (1999) 'Learning orientation, market orientation, and innovation: Integrating and extending models of organizational performance', Journal of Market-Focused Management, Vol. 4, No. 4, pp.295-308.

Baltacioglu, T., Ada, E., Kaplan, M.D., Yurt O. and and Kaplan, Y.C. (2007) 'A new framework for service supply chains', The Service Industries Journal, Vol. 27, No. 2, pp.105-124.

Banerjee, S.B. (2002) 'Corporate environmentalism: the construct and its measurement', Journal of Business Research, Vol. 55, No. 3, pp.177-191.

Barney, J. (1991) 'Firm resources and sustained competitive advantage', Journal of Management, Vol. 17, No. 1, pp.99-120.

Berman, S.L., Wicks, A.C., Kotha, S. and Jones, T.M. (1999) 'Does stakeholder orientation matter? The relationship between stakeholder management models and firm financial performance', Academy of Management Journal, Vol. 42, No. 5, pp.488-506.

Bines, J.E. and Jamieson, P. (2013) 'Designing new collaborative learning spaces in clinical environments: experiences from a children's hospital in Australia', Journal of Interprofessional Care, Vol. 27, No. 2, pp.63-68.

Birkinshaw, J., Crilly, D., Bouquet, C. and Lee, S.Y. (2016) 'How do firms manage strategic dualities? A process perspective', Academy of Management Discoveries, Vol. 2, No. 1, pp.51-78.

Blome, C., Hollos, D. and Paulraj, A. (2014) 'Green procurement and green supplier development: antecedents and effects on supplier performance', International Journal of Production Research, Vol. 52, No. 1, pp.32-49.

Boon-Itt, S. and Wong, C.Y. (2011) 'The moderating effects of technological and demand uncertainties on the relationship between supply chain integration and customer delivery performance', Vol. 41, No. 3, pp.253-276.

Cachon, G.P. (2003) 'Supply chain coordination with contracts', Handbooks in Operations Research and Management Science, Vol. 11, No. 5, pp.227-339.

Cao, M. and Zhang, Q. (2011) 'Supply chain collaborative advantage: a firm's perspective', International Journal of Production Economics, Vol. 128, No. 1, pp.358-367.

Chakraborty, S., Bhattacharya, S. and Dobrzykowski, D.D. (2014) 'Impact of supply chain collaboration on value co-creation and firm performance: a healthcare service sector perspective', Procedia Economics and Finance, Vol. 11, No. 7, pp.676-694.

Chan, R.Y., He, H., Chan, H.K. and Wang, W.Y. (2012) 'Environmental orientation and corporate performance: the mediation mechanism of green supply chain management and moderating effect of competitive intensity', Industrial Marketing Management, Vol. 41, No. 4, pp.621-630.

Cheng, J.H. (2011) 'Inter-organizational relationships and information sharing in supply chains', International Journal of Information Management, Vol. 31, No. 4, pp.374-384.

Chin, W.W. (1998) 'The partial least squares approach to structural equation modeling', Modern Methods for Business Research, Vol. 295, No. 2, pp.295-336. 
Crane, A., Matten, D. and Moon, J. (2008) 'Ecological citizenship and the corporation: politicizing the new corporate environmentalism', Organization \& Environment, Vol. 21, No. 4, pp.371-389.

Croom, S., Vidal, N., Spetic, W., Marshall, D. and McCarthy, L. (2018) 'Impact of social sustainability orientation and supply chain practices on operational performance', International Journal of Operations \& Production Management.

CSC Consulting (1996) Efficient Healthcare Consumer Response: Improving the Efficiency of the Healthcare Supply Chain, CSC Consulting, Cleveland, OH.

De Clercq, D. and Belausteguigoitia, I. (2017) 'Overcoming the dark side of task conflict: buffering roles of transformational leadership, tenacity, and passion for work', European Management Journal, Vol. 35, No. 1, pp.78-90.

Defee, C.C. and Fugate, B.S. (2010) 'Changing perspective of capabilities in the dynamic supply chain era', The International Journal of Logistics Management, Vol. 21, No. 2, pp.180-206.

Deutscher, F., Zapkau, F.B., Schwens, C., Baum, M. and Kabst, R. (2016) 'Strategic orientations and performance: a configurational perspective', Journal of Business Research, Vol. 69,No. 2, pp.849-861.

Dillman, D.A. (2011) Mail and Internet Surveys: The Tailored Design Method - 2007 Update with New Internet, Visual, and Mixed-Mode Guide, John Wiley \& Sons.

Dillon, K. and Prokesch, S. (2010) 'Global challenges in health care: Is rationing in our future?', Harvard Bus. Rev., Apr.

Dobrzykowski, D.D. and Tarafdar, M. (2015) 'Understanding information exchange in healthcare operations: evidence from hospitals and patients', Journal of Operations Management, Vol. 36, No. 2, pp.201-214.

Dyer, J.H. and Singh, H. (1998) 'The relational view: cooperative strategy and sources of interorganizational competitive advantage', Academy of Management Review, Vol. 23, No. 4, pp.660-679.

Esper, T.L., Defee, C.C. and Mentzer, J.T. (2010) 'A framework of supply chain orientation', The International Journal of Logistics Management, Vol. 21, No. 2, pp.161-179.

Esper, T.L., Fugate, B.S. and Davis-Sramek, B. (2007) 'Logistics learning capability: sustaining the competitive advantage gained through logistics leverage', Journal of Business Logistics, Vol. 28, No. 2, pp.57-82.

Fatovich, D.M., Nagree, Y. and Sprivulis, P. (2005) 'Access block causes emergency department overcrowding and ambulance diversion in Perth, Western Australia', Emergency Medicine Journal, Vol. 22, No. 5, pp.351-354.

Fawcett, S.E. and Magnan, G.M. (2004) 'Ten guiding principles for high-impact SCM', Business Horizons, Vol. 47, No. 5, pp.67-74.

Fawcett, S.E., McCarter, M.W., Fawcett, A.M., Webb, G.S. and Magnan, G.M. (2015) 'Why supply chain collaboration fails: the socio-structural view of resistance to relational strategies', Supply Chain Management: An International Journal, Vol. 20, No. 6, pp.648-663.

Fayezi, S., Zutshi, A. and O'Loughlin, A. (2017) 'Understanding and development of supply chain agility and flexibility: a structured literature review', International Journal of Management Reviews, Vol. 19, No. 4, pp.379-407.

Fraj, E., Matute, J. and Melero, I. (2015) 'Environmental strategies and organizational competitiveness in the hotel industry: the role of learning and innovation as determinants of environmental success', Tourism Management, Vol. 46, No. 1, pp.30-42.

Garcia-Dastugue, S.J. and Lambert, D.M. (2003) 'Internet-enabled coordination in the supply chain', Industrial Marketing Management, Vol. 32, No. 3, pp.251-263.

Giannoccaro, I. and Pontrandolfo, P. (2002) 'Inventory management in supply chains: a reinforcement learning approach', International Journal of Production Economics, Vol. 78, No. 2, pp.153-161. 
Hair, J., Hollingsworth, C.L., Randolph, A.B. and Chong, A.Y.L. (2017a) 'An updated and expanded assessment of PLS-SEM in information systems research', Industrial Management and Data Systems, Vol. 117, No. 3, pp.442-458.

Hair, J.F., Hult, G.T.M., Ringle, C.M. and Sarstedt, M. (2017b) A Primer on Partial Least Squares Structural Equation Modeling, 2nd ed., Sage, Thousand Oaks.

Hair, J.F., Black, B.B., Babin, B.B., Anderson, R. and Tatham, R. (2006) Multivariate Data Analysis, Prentice-Hall, Upper Saddle, NJ.

Hair, J.F., Hult, G.T.M., Ringle, C.M. and Sarstedt, M. (2014) A Primer on Partial Least Squares Structural Equation Modeling, Sage, Thousand Oaks, CA.

Hair, J.F., Ringle, C.M. and Sarstedt, M. (2011) 'PLS.SEM: indeed a silver bullet', Journal of Marketing Theory and Practice, Vol. 19, No. 2, pp.139-152.

Hair, J.F., Sarstedt, M., Ringle, C.M. and Gudergan, S.P. (2018) Advanced Issues in Partial Least Squares Structural Equation Modeling (PLS-SEM), Sage, Thousand Oaks, CA.

Hair, J.F., Sarstedt, M., Ringle, C.M. and Mena, J.A. (2012) 'An assessment of the use of partial least squares structural equation modeling in marketing research', Journal of the Academy of Marketing Science, Vol. 40, No. 3, pp.414-433.

Henseler, J. and Dijkstra, T.K. (2015) ADANCO 2.1.1 Kleve, Composite Modeling, Germany.

Henseler, J., Hubona, G. and Ray, P.A. (2016) 'Using PLS path modeling in new technology research: updated guidelines', Industrial Management and Data Systems, Vol. 116, No. 1, pp.2-20.

Henseler, J., Ringle, C.M. and Sarstedt, M. (2015) 'A new criterion for assessing discriminant validity in variance-based structural equation modeling', Journal of the Academy of Marketing Science, Vol. 43, No. 1, pp.115-135.

Hossain, L. and Guan, D.C.K. (2012) 'Modelling coordination in hospital emergency departments through social network analysis', Disasters, Vol. 36, No. 2, pp.338-364.

Janaína, D.A., Diniz, S. and Fabbe-Costes, N. (2007) 'Supply chain management and supply chain orientation: key factors for sustainable development projects in developing countries?', International Journal of Logistics Research and Applications, Vol. 10, No. 3, pp.235-250.

Jyoti, J. and Dev, M. (2015) 'The impact of transformational leadership on employee creativity: the role of learning orientation', Journal of Asia Business Studies, Vol. 9, No. 1, pp.78-98.

Kaya, N. and Patton, J. (2011) 'The effects of knowledge-based resources, market orientation and learning orientation on innovation performance: an empirical study of Turkish firms', Journal of International Development, Vol. 23, No. 2, pp.204-219.

Kirchoff, J.F., Tate, W.L. and Mollenkopf, D.A. (2016) 'The impact of strategic organizational orientations on green supply chain management and firm performance', International Journal of Physical Distribution and Logistics Management, Vol. 46, No. 3, pp.269-292.

Kobayashi, M., Fussell, S.R., Xiao, Y. and Seagull, F.J. (2005) 'Work coordination, workflow, and workarounds in a medical context', in CHI'05 Extended Abstracts on Human Factors in Computing Systems, ACM, April, pp.1561-1564.

Lambe, C.J., Spekman, R.E. and Hunt, S.D. (2002) 'Alliance competence, resources, and alliance success: conceptualization, measurement, and initial test', Journal of the Academy of Marketing Science, Vol. 30, No. 2, pp.141-158.

Lejeune, M.A. and Yakova, N. (2005) 'On characterizing the 4 C's in supply chain management', Journal of operations Management, Vol. 23, No. 1, pp.81-100.

Mandal, S. (2017) 'The influence of dynamic capabilities on hospital-supplier collaboration and hospital supply chain performance', International Journal of Operations \& Production Management.

Mandal, S. (2018) 'Exploring the influence of big data analytics management capabilities on sustainable tourism supply chain performance: the moderating role of technology orientation', Journal of Travel \& Tourism Marketing, Vol. 35, No. 8, pp.1104-1118. 
Matopoulos, A. and Michailidou, L. (2013a) 'Healthcare supply chains: a case study of hospital-vendor collaborative practices', International Journal of Logistics Systems and Management, Vol. 15, No. 2, pp.288-303.

Matopoulos, A. and Michailidou, L. (2013b) 'Implementing collaborative practices in the healthcare supply chain: insights into hospital-vendor operations', International Journal of Logistics Systems and Management, Vol. 15, Nos. 2-3, pp.288-303.

Matopoulos, A., Vlachopoulou, M., Manthou, V. and Manos, B. (2007) 'A conceptual framework for supply chain collaboration: empirical evidence from the agri-food industry', Supply Chain Management: An International Journal, Vol. 12, No. 3, pp.177-186.

Netting, F.E., Williams, F.G., Jones-Mcclintic, S. and Warrick, L. (1990) 'Policies to enhance coordination in hospital-based case management programs', Health and Social Work, Vol. 15, No. 1, pp.15-21.

Nordquist, J. and Laing, A. (2015) 'Designing spaces for the networked learning landscape', Medical Teacher, Vol. 37, No. 4, pp.337-343.

Peng, D.X. and Lai, F. (2012) 'Using partial least squares in operations management research: a practical guideline and summary of past research', Journal of Operations Management, Vol. 30, No. 6, pp.467-480.

Real, J.C., Roldán, J.L. and Leal, A. (2014) 'From entrepreneurial orientation and learning orientation to business performance: analysing the mediating role of organizational learning and the moderating effects of organizational size', British Journal of Management, Vol. 25, No. 2, pp.186-208.

Ren, Y., Wang, A. and Wang, H. (2014) 'Fault diagnosis and tolerant control for discrete stochastic distribution collaborative control systems', IEEE Transactions on Systems, Man, and Cybernetics: Systems, Vol. 45, No. 3, pp.462-471.

Richter, N.F., Carrión, G.C., Roldán, J.L. and Ringle, C.M. (2016) 'European management research using partial least squares structural equation modeling (PLS.SEM): editorial', European Management Journal, Vol. 34, No. 6, pp.589-597.

Ringle, C.M., Wende, S. and Will, A. (2005) SmartPLS 2.0.M3, SmartPLS, Hamburg [online] http://www.smartpls.com (accessed 16 December 2018).

Schmitt, A.J. and Snyder, L.V. (2012) 'Infinite-horizon models for inventory control under yield uncertainty and disruptions', Computers \& Operations Research, Vol. 39, No. 4, pp.850-862.

Scholten, K. and Schilder, S. (2015) 'The role of collaboration in supply chain resilience', Supply Chain Management: An International Journal, Vol. 20, No. 4, pp.471-484.

Simchi-Levi, D., Kaminsky, P. and Simchi-Levi, E. (1999) Designing and Managing the Supply Chain: Concepts, Strategies, and Cases, McGraw-Hill, New York.

Simmons, B.L. and White, M.A. (1999) 'The relationship between ISO 9000 and business performance: does registration really matter?', Journal of Managerial Issues, Vol. 31, No. 7, pp.330-343.

Sinkovics, R.R., Jean, R.J.B., Roath, A.S. and Cavusgil, S.T. (2011) 'Does IT integration really enhance supplier responsiveness in global supply chains?', Management International Review, Vol. 51, No. 2, p.193.

Stern, W.L., El-Ansari, A.I. and Coughlan, A.T. (1996) Marketing Channels, 5th ed., Prentice-Hall, London.

Stern, Z., Katz-Navon, T. and Naveh, E. (2008) 'The influence of situational learning orientation, autonomy, and voice on error making: the case of resident physicians', Management Science, Vol. 54, No. 9, pp.1553-1564.

Tan, K.C., Lyman, S.B. and Wisner, J. D. (2002) 'Supply chain management: a strategic perspective', International Journal of Operations \& Production Management.

Teece, D.J. (2012) 'Dynamic capabilities: routines versus entrepreneurial action', Journal of Management Studies, Vol. 49, No. 8, pp.1395-1401. 
VanVactor, J.D. (2011) 'A case study of collaborative communications within healthcare logistics', Leadership in Health Services, Vol. 24, No. 1, pp.51-63.

Visser, P.S., Krosnick, J.A., Marquette, J. and Curtin, M. (1996) 'Mail surveys for election forecasting? An evaluation of the Columbus Dispatch poll', Public Opinion Quarterly, Vol. 60, No. 2, pp.181-227.

Vos, G.C.J.M. and Meijboom, B.R. (2004) 'International supply chain management: three different perspectives', in The Emerging World of Chain and Networks: Bridging Theory and Practice, pp.49-72, Reed Business Information.

Wilder, B. and Stanley, K. (2015) 'Reconciling explanations for the evolution of evolvability', Adaptive Behavior, Vol. 23, No. 3, pp.171-179.

Wowak, K.D., Craighead, C.W., Ketchen Jr., D.J. and Hult, G.T.M. (2013) 'Supply chain knowledge and performance: a meta-analysis', Decision Sciences, Vol. 44, No. 5, pp.843-875.

Xu, K., Dong, Y. and Evers, P.T. (2001) 'Towards better coordination of the supply chain', Transportation Research Part E: Logistics and Transportation Review, Vol. 37, No. 1, pp.35-54.

Zhao, X., Lynch Jr., J.G. and Chen, Q. (2010) 'Reconsidering Baron and Kenny: myths and truths about mediation analysis', Journal of Consumer Research, Vol. 37, No. 2, pp.197-206.

Zhou, K.Z. and Li, C.B. (2010) 'How strategic orientations influence the building of dynamic capability in emerging economies', Journal of Business Research, Vol. 63, No. 3, pp.224-231. 